\title{
NEW CHOROLOGICAL DATA FOR RARE VASCULAR PLANTS FROM ROMANIA
}

\author{
ANASTASIU Paulina ${ }^{1}$
}

\begin{abstract}
New chorological data about seven rare vascular plant taxa are reported in the present paper: Conringia austriaca, Jurinea multiflora, Linaria arvensis, Nonea pallens, Ophrys apifera, Ophrys scolopax subsp. cornuta, Saponaria officinalis. For Linaria arvensis, previously considered doubtful in the absence of the herbarium material, we confirm its presence in Romania. The report of Nonea pallens is the first for Dobrogea, while the report of Jurinea multiflora is the first for Muntenia region of Romania.

Keywords: chorological data, flora, rare plants, Romania
\end{abstract}

Received 9 March 2015

Accepted 3 April 2015

\section{Introduction}

During various field studies in the period 2010-2014, new data on the occurrence of some native vascular plant species have obtained. They are rare species (Oltean et al. 1994), generally with a very limited distribution not only in Romania, but also in Europe (Tutin et al. 1964-1980, Tutin et al. 1993).

The nomenclature is according to The Plant List (2013). Beside the new chorological data, the geographic coordinates (decimal degrees, WGS 1984 system) are given, as well as a discussion about their distribution in Romania. Furthermore, the voucher specimen is indicated, the herbarium code being according to Index Herbariorum (Thiers, continuously updated).

\section{Results and disscusion}

Conringia austriaca (Jacq.) Sweet (Fam. Brassicaceae)

Dobrogea, Constanța County: Şipotele E, near the village, bushes with Paliurus spina-christi, 19.04.2010; Sipotele S, Izlaz Hill, bushes, $44.026147^{\circ} \mathrm{N}, 27.950989^{\circ} \mathrm{E}$, 30.04.2010; SSipotele E, near village, rocky grassland, $44.050405^{\circ} \mathrm{N}, 27.965562^{\circ} \mathrm{E}$, 30.04.2010; Sipotele E, edge of bushes with Paliurus spina-christi, 21.05.2010 [CL 661637; CL 661638].

According to Oprea (2005), the plant has previously been reported only from a few counties, as follows: Bihor County - in the natural reserve Defileul Crişului Repede; Cluj County - Cheile Turzii; Sibiu County - Bungard, Şura Mare, Slimnic; Mehedinți County - Gura Văii, Vârciorova to Porțile de Fier and Gura Slătinicului; Tulcea County - Atmagea on Ghiubelca valley. This last specification is the only existing one to date in Dobrogea.

\footnotetext{
${ }^{1}$ University of Bucharest, Faculty of Biology and Botanic Garden "D. Brandza", 1-3, Intr. Portocalelor, Sector 6, 060101 - Bucureşti, Romania, e-mail: anastasiup@yahoo.com
} 
Distribution in Europe: SE \& EC Europe, extending westwards to Austria and Sardinia (Ball 1993, Marhold 2011a).

Jurinea multiflora (L.) B.Fedtsch. [syn. Jurinea linearifolia (DC.) DC.] (Fam. Compositae) (Fig. 1)

Muntenia, Buzău County: Balta Albă S, $45.278428^{\circ}$ N, $27.291308^{\circ} \mathrm{E}$, ca. $45 \mathrm{~m}$ alt., 02.07.2013 and 19.07.2013. The plants (three flowering individuals) have been recorded in dry grassland with Festuca valesiaca, Agropyron cristatum s.1., Tanacetum millefolium, Teucrium chamaedrys, Bassia prostrata, Stipa capillata, Astragalus austriacus, Linum perenne, Bothriochloa ischaemum. In the same habitat with Jurinea multiflora we also identified four rare species for Romania (Oltean et al. 1994): Allium denudatum (syn. Allium albidum), Astragalus dasyanthus, Goniolimon besserianum, Tanacetum millefolium.

Jurinea multiflora is a perennial species, woody at base, with lanceolate or linear-lanceolate, shortly acuminate, usually with revolute margin, arachnoid-tomentose leaves. Capitula are small $(5-20 \mathrm{~mm})$, cylindrical, with involucral bracts shortly acuminate, white or pale green below, pink or reddish-purple distally, with scarious apex. Achenes are tetragonal, ribbed, glabrous, with pappus ca. 3 times as long as achene (Kožuharov 1976). This taxa is very closed to Jurinea tzar-ferdinandii, but the latter has involucral bracts white or pale green distally. It is also related to Jurinea stoechadifolia, but this species has larger capitula $(27-30 \mathrm{~mm})$. Both J. tzar-ferdinandii and $J$. stoechadifolia have been reported for Romania.

Jurinea multiflora is a continental element (Dihoru \& Negrean 2009, Sârbu et al. 2013), with general distribution in S \& SE parts of former U.S.S.R., SE Romania, growing in steppes and semideserts (Kožuharov 1976, Greuter 2006+).

This species has been reported for Romania only in two counties in the E-SE part of the country, as follows: Constanța County, Nistoreşti (Horeanu 1972), Medgidia (Prodan 1957); Galați County, Galați city, near Brateş Lake (Herbarium C. Zahariadi according to Dihoru \& Negrean 2009). Sârbu et al. (2013) mention it as a rare species in the steppe area, dry grassland and stony hills, in Agropyro-Kochietum prostratae association. The status of Jurinea multiflora has been appreciated as critically endangered (Dihoru \& Negrean 2009) or vulnerable (Oprea 2005).

The field research in Nistoreşti and Brateş Lake area does not confirm the presence of the plant for these locations. The presence of the species in Medgidia is difficult to verify because the area is quite large, and the bibliography does not indicate a specific location. We note that there are no herbaria specimens collected in Romania.

Our information is the first one on the presence of the species in Muntenia choronyms of Tulcea and Galati, mentioned in the literature, are located in Dobrogea, respectively in Moldova regions. At the same time this data confirms the presence of the plant in the Romanian Flora.

Linaria arvensis Desf. (syn. Antirrhinum arvense L.) (Fam. Plantaginaceae)

Transylvania, Hunedoara County: Sălaşu de Sus, the natural reserve Fânațele cu narcise, in ruderal places (wayside), with only few accompanying species (Polygonum aviculare, Persicaria hydropiper, Erigeron annuus s.1.), $45.500739^{\circ} \mathrm{N}, 22.947352^{\circ} \mathrm{E}$, ca. $515 \mathrm{~m}$ alt., 11\&12.08.2013 [BUC 402223; BUC 402224].

Banat, Caraş-Severin: Coronini, $44.671233^{\circ} \mathrm{N}, 21.751248^{\circ} \mathrm{E}$, ca. $400 \mathrm{~m}$ alt., 29.08.2014. The plants have been identified in disturbed soil on the platform around a 
wind turbine, accompanied by the following species: Dactylis glomerata s.1., Anthyllis vulneraria s.1., Fragaria vesca, Medicago falcata, Cerastium fontanum s.1., Hypericum elegans, Stellaria graminea, Galium verum, Bothriochloa ischaemum, Elymus repens s.l., Chondrilla juncea, Geranium lucidum, Trifolium arvense, Scabiosa arvensis, Plantago lanceolata, Salvia verticillata, Leucanthemum vulgare, Carduus acanthoides, Lotus corniculatus, Achillea setacea, Linaria vulgaris, Trifolium pratense, Potentilla argentea, Convolvulus arvensis, Teucrium chamaedrys, Tanacetum vulgare, Rumex acetosella, Dianthus carthusianorum, Centaurea phrygia, Agrimonia eupatoria, Rubus caesius, Trifolium repens. According to Sârbu et al. (2013), it grows in sandy, ruderal and cultivated places, in plains and hills, in Centauretalia cyani.

Linaria arvensis is a Central European element (Ciocârlan 2009, Sârbu et al. 2013), with large distribution in European countries (Marhold 2011c). The presence in Romania was considered uncertain in the absence of herbarium material (Chater et al. 1972, Oprea 2005, Ciocârlan 2009, Sârbu et al. 2013). However, the plant was mentioned in several counties: Satu Mare, Cluj, Mureş, Harghita, Braşov, Alba, Sibiu, Iaşi, Suceava, Botoşani, Tulcea (Marian 2000, Oprea 2005, Ciocârlan 2009, Sîrbu \& Oprea 2011, Sârbu et al. 2013). Sîrbu \& Oprea (2011) consider this species as allochtonous for Romania.

The two choronyms indicated above confirm the presence of the species in the country and are the first reports for Hunedoara and Caraş-Severin counties.

Nonea pallens Petrovič (Fam. Boraginaceae)

Dobrogea, Constanța County: Şipotele N, grassland near the road, $44.062817^{\circ} \mathrm{N}$, 27.971017 ${ }^{\circ} \mathrm{E}, 19.04 .2010$; Şipotele SE, secondary grassland, near the road ŞipoteleTufani, $44.028067^{\circ} \mathrm{N}, 27.971000^{\circ} \mathrm{E}$, ca. $140 \mathrm{~m}$ alt., 29.04.2010 [CL 661664]; Sevendic $\mathrm{N}-\mathrm{NE}$, grassland, $44.019683^{\circ} \mathrm{N}, 27.950200^{\circ} \mathrm{E}, 30.04 .2010$; Deleni N-NE, Cişmeluței Valley, grassland, 22.05.2010; Zorile W-SW, Ghiolpunar Hill, grassland, $44.075567^{\circ} \mathrm{N}$, 27.91006 $7^{\circ} \mathrm{E}, 23.05 .2010$; Zorile W-SW, Ghiolpunar Hill, edge of agriculture field, 07.06.2010; Deleni, Refugiului Valley, stony grassland, $44.104933^{\circ} \mathrm{N}, 28.002250^{\circ} \mathrm{E}$, 07.06.2010.

According to Ciocârlan (2009) and Sârbu et al. (2013), Nonea pallens is a PontoBalkan element. It is spread in SE Europe, from Albania to S Ukraine (Chater 1972, Valdés 2011), native in most of countries, except Republic of Moldova where it is considered an introduced species (Valdés 2011). From Romania, it was reported from the SW of the country, in Mehedinți County, from Gura Văii to Vârciorova (Grecescu 1898) and in grasslands from Gura Oglănicului to Gura Slătinicului (Roman 1974). The first record in Dobrogea was communicated at a national scientific symposium in 2010 (Anastasiu 2010a) and subsequently some further information (“Constanța: Şipotele către păd. Deleni”) was published by Sârbu et al. (2013). The occurrence of Nonea pallens in SE of the country demonstrates a continuity of the distribution area between Bulgaria and Ukraine.

Ophrys apifera Huds. subsp. apifera (Fam. Orchidaceae) (Fig. 2)

Muntenia, Buzău County: Cocârceni, grassland, $45.363671^{\circ} \mathrm{N}, 26.486291^{\circ} \mathrm{E}$, ca. $440 \mathrm{~m}$ alt., 01.06.2014, two mature individuals. Ophrys apifera subsp. apifera is an Atlantic-Mediterranean taxon (Sârbu et al. 2013), previously reported only from a few counties in Romania: Sibiu, Hunedoara, Mehedinți, Dâmbovița, Prahova (Oprea 2005, Sârbu et al. 2013). This taxon is appreciated as critically endangered at national level 
(Dihoru \& Negrean 2009), but as "least concern" in the IUCN Red List (Bilz et al. 2011). This report is the first one for Buzău County.

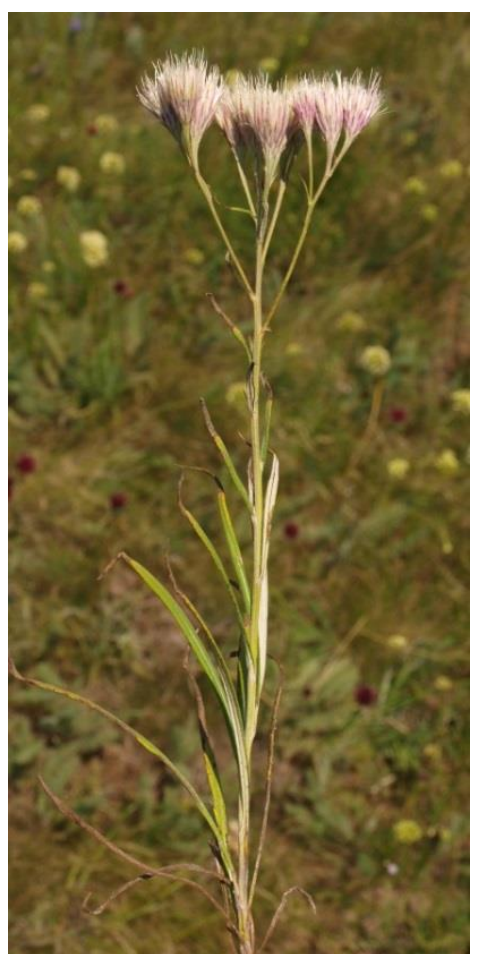

Fig. 1. Jurinea multiflora, Balta Albă, Buzău County, 02.07.2013 (photo: P. Anastasiu)

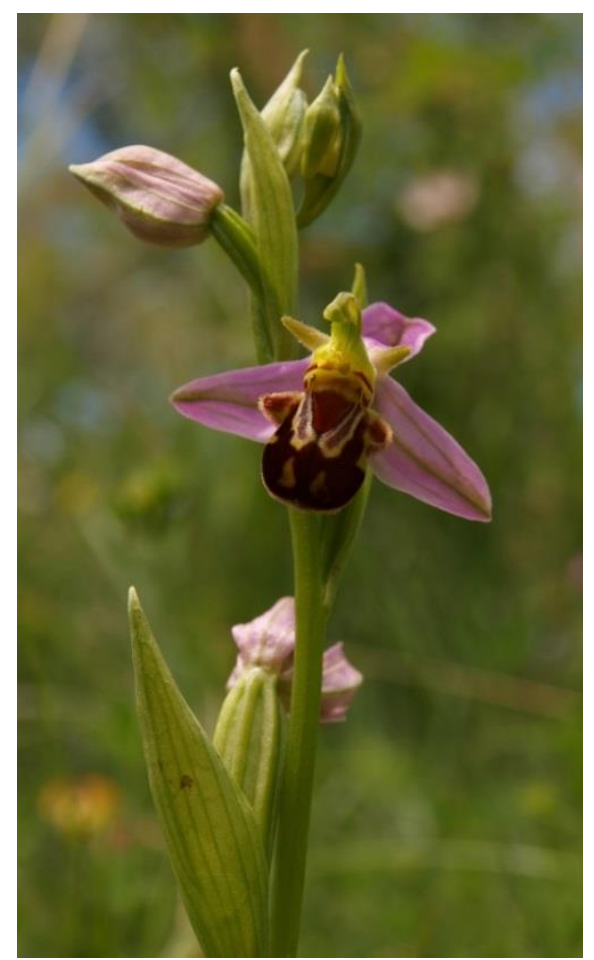

Fig. 2. Ophrys apifera subsp. apifera, Cocârceni, Buzău County, 01.06.2014 (photo: P. Anastasiu)

Ophrys scolopax Cav. subsp. cornuta (Steven) Camus (Fam. Orchidaceae)

Muntenia, Buzău County: Ulmet, bushes with Hippophaë rhamnoides s.l., $45.368787^{\circ} \mathrm{N}, 26.465205^{\circ} \mathrm{E}$, ca. $470 \mathrm{~m}$ alt., 09.06.2014 [BUC 401676]. This is the fifth report from Buzău County, the plant having been previously reported from Cislău (Nyárády \& Beldie 1972, Oprea 2005, Dihoru \& Negrean 2009), Pătârlagele (Popova et al. 1981 in Oprea 2005), Căneşti (Anastasiu et al. 2008) and Cocârceni (Anastasiu 2010b). Ophrys scolopax subsp. cornuta is very rare in Romania and critically endangered (Dihoru \& Negrean 2009). It has been reported from Banat, Oltenia, Muntenia, Moldova (Oprea 2005, Sâbu et al. 2013).

Saponaria glutinosa M.Bieb. (Fam. Caryophyllaceae)

Dobrogea, Constanța County: Şipotele E, at the edge of Ponto-Sarmatic deciduous thickets, $44.050417^{\circ} \mathrm{N}, 27.965000^{\circ} \mathrm{E}, 21.05 .2010$ [CL 661639]; Dumbrăveni, at the edge of forest, 02.06.2011. Considered a Mediterranean species (Dihoru \& Negrean 2009), Saponaria glutinosa is distributed in SE Europe and Spain (Chater 1993, Marhold 2011b). It is rare in Romania, reported from a few places in Mehedinți 
County and Constanța County - Dumbrăveni, Canaraua Fetii (Arcuş 1998). Its status in Romania has been appreciated as being at Low Risk (Dihoru \& Negrean 2009).

Acknowledgements. I am indebted to Cristina Bogdan who verified the presence of Jurinea multiflora in Galați County, as well as to Mr. Negrean Gavril for the helpful comments on the manuscript.

\section{References}

Anastasiu, P., Pascale, G. \& Cristurean, I. (2008). Regarding grasslands between Sărățelului Valley and Slănicului Valley, Buzău County. Analele Univ. din Craiova. Agricultură, Montanologie, Cadastru, 38/B, 11-25.

Anastasiu, P. (2010a). Contributions to the knowledge rare and endangered plants from Adamclisi-Deleni area, Constanța County. A XVI-a Sesiune Anuală de Comunicări Ştiințifice a Grădinii Botanice „D. Brandza”, 5-6 Noiembrie 2010, București.

Anastasiu, P. (2010b). Contributions to chorological data on Romanian flora. Acta Horti Bot. Bucurest., 37, 45-50.

Arcuş, M. (1998). Flora vasculară şi vegetația rezervațiilor forestiere din sudul Dobrogei: Esechioi, Canaraua Fetii, Dumbrăveni şi Hagieni. Teză de doctorat. Iaşi: Universitatea „A.I. Cuza” din Iaşi.

Ball, P.W. (1993). Conringia Adanson. In T.G. Tutin, N.A. Burges, A.O. Chater, J.R Edmondson, V.H. Heywood, D.M. Moore, D.H. Valentine, S.M. Walters, D.A. Webb (eds.), Flora Europaea. Volume 1. Psilotaceae to Platanaceae. Second Edition (pp. 403). Cambridge: Cambridge University Press.

Bilz, M., Kell, S.P., Maxted, N. \& Lansdown, R.V. (2011). European Red List of Vascular Plants. Luxembourg: Publications Office of the European Union.

Chater, A.O., Valdés, B. \& Webb, D.A. (1972). Linaria Miller. In T.G. Tutin, V.H. Heywood, N.A. Burges, D.M. Moore, D.H. Valentine, S.M. Walters \& D.A. Webb (eds), assist. by P.W. Ball, A.O. Chater, R.A. DeFilipps, I.K. Ferguson \& I.B.K. Richardson, Flora Europaea. Volume 3. Diapensiaceae to Myoporaceae (pp. 226-236). Cambridge: Cambridge University Press.

Chater, A.O. (1972). Nonea Medicus. In T.G. Tutin, V.H. Heywood, N.A. Burges, D.M. Moore, D.H. Valentine, S.M. Walters \& D.A. Webb (eds), assist. by P.W. Ball, A.O. Chater, R.A. DeFilipps, I.K. Ferguson \& I.B.K. Richardson, Flora Europaea. Volume 3. Diapensiaceae to Myoporaceae (pp. 102-103). Cambridge: Cambridge University Press.

Chater, A.O. (1993). Saponaria L. In T.G. Tutin, N.A. Burges, A.O. Chater, J.R. Edmondson, V.H. Heywood, D.M. Moore, D.H. Valentine, S.M. Walters, D.A. Webb (eds.), Flora Europaea. Volume 1. Psilotaceae to Platanaceae. Second Edition (pp. 223-224). Cambridge: Cambridge University Press.

Ciocârlan, V. (2009). Flora Ilustrată a României. Pteridophyta et Spermatophyta. Ediția a III-a. Bucureşti: Edit. Ceres.

Dihoru, G. \& Negrean, G. (2009). Cartea roşie a plantelor vasculare din România. București: Edit. Academiei Române.

Grecescu, D. (1898). Conspectul Florei României. Bucureşti: Tipografia "Dreptatea".

Greuter, W. (2006+). Compositae (pro parte majore). In Euro+Med Plantbase - the information resource for Euro-Mediterranean plant diversity. Retrieved March 7, 2015 from: ww2.bgbm.org/EuroPlusMed/.

Horeanu, C. (1972). Jurinea linearifolia DC. în flora României. Lucr. Şti., Şti. Nat., Bot., Inst. Pedag. Constanța /1972/, 107-109. 
Kožuharov, S. (1976). Jurinea Cass. In T.G. Tutin, V.H. Heywood, N.A. Burges, D.M. Moore, D.H. Valentine, S.M. Walters, D.A. Webb (eds.), Flora Europaea. Volume 4. Plantaginaceae to Compositae (and Rubiaceae) (pp. 218-220). Cambridge: Cambridge University Press.

Marhold, K. (2011a). Brassicaceae. In Euro+Med Plantbase - the information resource for Euro-Mediterranean plant diversity. Retrieved March 7, 2015 from: ww2.bgbm.org/EuroPlusMed/.

Marhold, K. (2011b). Caryophyllaceae. In Euro+Med Plantbase - the information resource for Euro-Mediterranean plant diversity. Retrieved March 7, 2015 from: ww2.bgbm.org/EuroPlusMed/.

Marhold, K. (2011c). Scrophulariaceae. In Euro+Med Plantbase - the information resource for Euro-Mediterranean plant diversity. Retrieved March 7, 2015 from: ww2.bgbm.org/EuroPlusMed/.

Marian, M. (2000). Contribuții la completarea listei floristice a județului Satu Mare / Contributions to the Floristical List of the Satu Mare County. Satu Mare, Stud. Comunic., Ser. Stti. Nat., Muzeul Județean Satu Mare, 1, 70-71.

Nyárády, A. \& Beldie, A. (1972). Genul 759. Ophrys L. In Săvulescu T. (ed.), Flora României, vol. 12 (pp. 655-662). Bucureşti: Edit. Academiei Române.

Oltean, M., Negrean, G., Popescu, A., Roman, N., Dihoru, G., Sanda, V. \& Mihăilescu S. (1994). Lista roşie a plantelor superioare din România. In M. Oltean (coord.), Studii, sinteze, documentații de ecologie, Academia Română, Institutul de Biologie, 1, 1-52.

Oprea, A. (2005). Lista critică a plantelor vasculare din România. Iaşi: Edit. Univ. “A. I. Cuza".

Prodan, I. (1957). Contribuții la flora R.P.R. /România/. Bul. Şt. Secț. Biol. Şti. Agric. (Ser. Bot.) 9(4), 285-326.

Roman, N. (1974). Flora şi vegetația din sudul Podişului Mehedinți. Bucureşti: Edit. Academiei Române.

Sîrbu, C. (coord.) \& Oprea, A. (2011). Plante adventive în flora României. Iaşi: Edit. "Ion Ionescu de la Brad".

Sârbu, I., Ştefan, N. \& Oprea, A. (2013). Plante vasculare din România. Determinator de teren. Bucureşti: Edit. Victor B Victor.

The Plant List (2013). Version 1.1. Retrieved March 7, 2015 from http://www.theplantlist.org/.

Thiers, B. [continuously updated]. Index Herbariorum: A global directory of public herbaria and associated staff. New York Botanical Garden's Virtual Herbarium. Retrieved March 7, 2015 from http://sweetgum.nybg.org/ih/.

Tutin, T.G., Burges, N.A., Chater, A.O., Edmondson, J.R., Heywood, V. H., Moore, D.M., Valentine, D.H., Walters, S.M. \& Webb, D.A. (eds.) (1993). Flora Europaea. Volume 1. Psilotaceae to Platanaceae. Second Edition. Cambridge: Cambridge University Press.

Tutin, T.G., Heywood, V.H., Burges, N.A., Moore, D.M., Valentine, D.H., Walters, S.M. \& Webb D.A. (eds.) (1964-1980). Flora Europaea. Vols. 1-5. Cambridge: Cambridge University Press.

Valdés, B. (2011). Boraginaceae. In Euro+Med Plantbase - the information resource for Euro-Mediterranean plant diversity. Retrieved March 7, 2015 from: ww2.bgbm.org/EuroPlusMed/. 